\title{
ANALISIS PERGESERAN PANDANGAN POLITIK MASSA DARI PPP KE PKB1999 DI SAMPANG
}

\author{
Mustofa \\ PGSD, FKIP, Universitas Nahdlatul Ulama Surabaya \\ Email:mustofa@unusa.ac.id
}

\begin{abstract}
Abstrak. Lahirnya Partai Kebangkitan Bangsa pada 1998 menjadi sejarah penting dalam perpolitikan di Sampang. Kehadiaran PKB merubah peta politik Islam di sampang pascareformasi. Karena sebelum reformasi hanyaPartai Persatuan Pembangunan yang menjadi satusatunya partai Islam yang dianggap mewakili kepentingan Islam. Namun kekalahan PPP dari Golkar secara berturut-turut (1992 dan 1997) membuat massa PPP sangat kecewa. Apalagi tragedi 1997 yaitu kerusuan massal yang menelan banyak korban dari pihak massa PPP tidak mampu diselesaikan oleh Kiai Alawy Muhammad yang menjadi tokoh sentral PPP. Akumulasi kekecewaan kemudian mendapatkan saluran saat PKB lahir dan dideklarasikan sebagai partainya "orang-orang" NU. Mayoritas pemilih Sampang adalah NU, ormas ini begitu dekat dan familiar dengan masyarakat, karena NU organisasi Islam yang digawangi oleh para kiai. Imigrasi para kiai ke PKB yang tidak sejalan dengan ijtihad politik Kiai Alawy Muhammad secara otomatis diikuti oleh mayoritas masyarakat Sampang. Kemudian pada pemilu 1999 PKB meraup suara mayoritas dan keluar menjadi pemenang dengan memeroleh 18 kursi di DPRD mengungguli partai-partai yang lain.
\end{abstract}

Kata kunci: Kiai, Islam, politik, PPP, PKB

\begin{abstract}
The birth of the National Awakening Party in 1998 became important in the history of politics in Sampang. The appearance of PKB changed the map of political Islam in the postreform lacquer. Because before the reformation of the United Development only Islamic party which was considered to represent the interests of Islam. When PPP was defeated by Golkar in a row (1992 and 1997) makes PPP masses felt very disappointed. Moreover, mass chaos on 1997, a tragedy that claimed many victims of the mass party PPP was not able to be coped by Kiai Alawy Muhammad who became the central figure of the PPP. Accumulated disappointing of people was inspired when PKB birth and declared as the party of NU "people". The majority of voters Sampang were NU, these organizations were so close and familiar with the community, because NU Islamic organization was leaded by "kiyai". The movement of kiyai that has not been in line with political of Kiai Alawy Muhammad's decision automatically followed by the majority in Sampang. Then in the 1999 election and a majority vote PKB scooped out a winner to obtain 18 seats in parliament out performed the other parties
\end{abstract}

Keyword: Kiai, Islam, politic, $P P P, P K B$ 


\section{PENDAHULUAN}

Perjuangan oreng kenek ${ }^{1}$ atau Masyarakat Sampang dalam mendukung Partai Persatuan Pembangunan (PPP) partai yang bebasis Islam bisa dikatakan belum membuahkan hasil yang diharapkan yaitu menjadi satusatunya partai yang kuat yang berkuasa di Sampang. Bahkan besar harapan mereka PPP bisa menang di Indonesia untuk memerjuangkan kepentingan-kepentingan Umat Islam. Pemilu 1992 dan Pemilu 1997 PPP dikalahkan oleh Golkar meskipun dengan berbagai kecurangan. Kiai Alawy Muhammad $^{2}$ yang menjadi alternatif sebagai panutan juga telah membuat masyarakat kecewa dengan sikap politiknya yang dianggap diluar kepentingan massa PPP.

Orde Reformasi diidentikkan dengan kebebasan. Untuk menampung dan menyalurkan secara terorganisasi aspirasi reformasi harus diakui ada kebutuhan obyektif untuk melahirkan Partai Politik Baru. Parpol baru diperlukan sebagai sarana mengonsolidasikan kekuatan reformasi untuk mencegah bangkitnya kekuatan-kekuatan represif untuk mengembalikan tatanan otoriter atau membangun sebuah otoriterisme baru. ${ }^{3}$

Pada 23 Juli 1998 KH Abdurrahman Wahid (Gusdur) bersama-sama warga Nahdlatul Ulama mendeklarasikan Partai Kebangkitan Bangsa (PKB) di Kompleks Masjidil Almunawwaroh di depan rumahnya, CiAnjur Jakarta Selatan, saat itu ia menjabat sebagai Ketua Umum PBNU. ${ }^{4}$ PKB adalah

\footnotetext{
${ }^{1}$ Oreng kenek adalah sebuah entitas unik dan penting dalam masyarakat Sampang. Mereka adalah golongan mayoritas yang berprofesi sebagai petani. Secara harfiah oreng kenek adalah orang kecil atau wong cilik tetapi dalam kontek sosial, politik, agama dan kebudayaan mereka memunyai ciri khas dan karakter yang tidak sama dengan orang kecil secara umum.

${ }^{2}$ Kiai Alawy Muhammad adalah sosok Kiai karismatis yang sangat disegani oleh Masyarakat Sampang. ia satu-satunya Jurkam PPP yang mampu memobilisasi massa dengan jargon-jargon Islamnya. Namun pasca kerusuhan 1997 popularitasnya memudar samasekali.

${ }^{3}$ Priyatmoko, Dilema dan Kontradiksi, Jawa Pos 31Juni-1998, hlm. 4.

${ }^{4}$ Deklarasi PKB dihadiri Try dan Edy Sudradjat, Jawa Pos, 24 Juli 1998, hlm. 1.
}

partai produk NU tidak mengherankan lambang yang digunakan mirip dengan simbol NU, yaitu bintang Sembilan dan bola dunia dengan transparansi kepulauan Indonesia. ${ }^{5}$ Bedanya lambang NU bertali yang seolah-olah mengikat bola dunia, sedangkang yang PKB tidak bertali.

NU kali pertama terjun dalam gelanggang politik praktis sebagai partai politik pada 1952 dan berhasil masuk tiga besar pada Pemilu 1955, setelah PNI dan Masyumi. Pada 1973 ketika Soeharto melakukan kebijakan fusi NU bergabung dengan partai-partai Islam lainnya ke dalam PPP, pasca-penggabungan, nasib NU bahkan lebih tragis lagi. ${ }^{6}$ Di tubuh PPP sendiri, NU merasa selalu menjadi korban politisasi, Gusdur sering menggambarkan NU sebagai pendorong mobil mogok, "Begitu mobilnya berjalan, NU pun ditinggalkan." Hal ini senada dengan yang disampaikan Kiai Muhammad Ishak bahwa orang-orang NU tidak mendapat tempat atau jabatan strategis di PPP meskipun basis massa NU paling besar. ${ }^{8}$

Kondisi semacam inilah yang mendorong para kiai membawa NU kembali ke khittahnya pada Muktamar ke-27 NU di Situbondo pad 1984. ${ }^{\circ}$ Khittah NU menghendaki netralitas kaum nahdliyin dalam politik praktis, sekalipun kontroversial gerakan kembali ke khittah terbukti ampuh mengembalikan elan vital NU sebagai gerakan masyarakat sipil yang disegani. Ketika Rezim Orde baru runtuh pada 1998 energi NU untuk berpartisipasi dalam memerbaiki kondisi politik bangsa menemukan momentumnya. ${ }^{10}$ Meskipun

\footnotetext{
${ }^{5}$ Ibid.,

${ }^{6}$ Masdar Hilmy, Peran Politik Ormas Islam, Dalam Kolom Opini, Kompas Amanat Hati Nurani Rakyat, 20 Juni 2015. hlm. 6.

${ }^{7}$ Ibid.

${ }^{8}$ Kiai Muhammad Ishak Ketua Partai Anak Cabang PKB Sampang, sebelum PKB lahir sejak 1983 sudah aktif di Partai Politik PPP di Sampang, kemudian saat PKB dideklarasikan ia termasuk salah satu tokoh Sampang yang berpindah hlmuan politik ke PKB

${ }^{9}$ Masdar Hilmy, op. cit.

${ }^{10} \mathrm{Ibid}$.
} 
tidak terjun secara langsung NU terlibat dalam pembentukan parpol seperti PKB. ${ }^{11}$

Bagi Masyarakat Madura dan bagi Umat Islam di Indonesia Agama Islam adalah agama yang final yang memunyai ajaran dan nilai-nilai absolut. Bahkan tindakan atau gerakan yang didasari oleh dorongan keagamaan terkadang tidak rasional dan obyektif. Menurut Weber, dibandingkan dengan rasionalitas instrumental, sifat rasionalitas yang berorientasi nilai yang penting adalah bahwa alat-alat hanya merupakan obyek pertimbangan dan perhitungan yang sadar, tujuan-tujuannya sudah ada dalam hubungannya dengan nilainilai individu atau kelompok yang bersifat absolut atau merupakan nilai akhir baginya. ${ }^{12}$

Weber menyatakan, tindakan religius mungkin merupakan bentuk dasar rasionalitas yang berorientasi nilai. Kehadiran Islam bagi Masyarakat Sampang adalah entitas yang harus dilindungi nilai yang harus dijaga sebagai wujud wahyu Tuhan yang akan membawa kedamaian dalam hati dan kemudian nilai-nilai lain seperti modernisasi tidak penting bagi mereka bahkan dianggap mengancam. Siapapun yang dianggap mengancam keberadaan Islam di daerah tersebut maka harus berhadapan dengan mereka walalupun harus dengan perang (jihad).

Sosok kiai memunyai posisi yang sentral dalam kehiduapn sehari-hari, baik segi agama, sosial, politik kiai tetap menjadi panutan bagi mereka. Pergeseran pandangan politik massatidak terlepas dari hijrahnya banyak kiaiyang dianggap sebagai pemimpin alternatif. Bahkan sejumlah mitos berkait dengan kiai melekat dalam masyarakatyang bersifat transedental. Benar atau tidak bahwa kiai memiliki kesaktian-kesaktian tersebut namun kepercayaan masyarakatadalah realitas yang tak terbantahkan. Maka, untuk menjelaskan fenomena ini perlu menggunakan teori Weber tentang otoritas karismatis. $^{13}$

\footnotetext{
${ }^{11}$ Ibid.

12 Doyle Paul Johnson, Teori Sosiologi Klasik dan Modern, Jakarta: Gramedia, 1986, hlm. 221.

${ }^{13}$ Ibid., hlm. 229-230.
}

Konsep Karisma diambil Weber dari konsep para ahli sejarah Gereja dan digunakan untuk kajian-kajian politik. Weber mendefinisikan karisma sebagai mutu tertentu yang melekat pada kepribadian seseorang yang menyebabkan ia dianggap sangat luar biasa dan diperlakukan orang sebagai seseorang yang dikaruniai kekuatan supranatural (ghaib), seorang manusia super atau setidak-tidaknya memunyai kekuatan atau kualitas istimewa. ${ }^{14}$ Dalam persoalanpersoalan politik berupa dominasi dan perlawanan harus melihat aspek-aspek kebudayaan, etos, mentalitas atau ideologi. ${ }^{15}$ Sistem patron-klien bergantung pada sistem nilai yang didasarkan pada etos tertentu yang meliputi penghormatan. Penghormatan yang berlebihan terhadap sosok Kiai yang dianggap suci membuat hegemoni kiai bersemai di kalangan masyarakat Sampang.

Kualitas adiduniawi merupakan kualitas ekslusif yang hanya dimiliki oleh kiai dalam kontek masyarakat Sampang, yang menarik para pengikut setia pada pemimpin karismatik secara pribadi dan memiliki komitmen terhadap keteraturan normatif atau moral yang digambarkannya dan berkaitan erat dengan nilai-nilai absolut yang diajarkannya, seperti ajaran-ajaran Islam. Maka, kiai tidak hanya menjadi pemimpin agama, namun dalam urusan politik dan bahkan segala urusan kehidupan oreng kenek selalu mengonsultasikan kepada kiai. ${ }^{16}$

\section{METODE}

Metode yang digunakan dalam penelitian ini meliputi empat tahap yaitu heuristik,

${ }^{14}$ Peter Burke, Sejarah dan Teori Sosial, Jakarta: Pustaka Obor Indonesia, 2011, hlm. 133.

${ }^{15} \mathrm{Ibid}$.

${ }^{16}$ Oreng kenek dalam urusan kehidupan baik itu karena persoalan hidup atau hanya sekadar petuah hidup selalu berkonsultasi dengan kiai yang disebut dengan istilah acabis, tradisi ini terus berlangsung hingga kini, pada umumnya oreng kenek meminta doadoa kepada kiai untuk dibuat amalan setiap hari, oreng kenek akan merasa damai dan tenang ketika semua sudah dikonsultasikan dengan kiai dan mendapat doadoa. 
kritik, interpretasi, dan historiografi. ${ }^{17}$ Selain itu juga memunyai sifat deskriptif analisis yang menyajikan data-data serta menginformasikan fakta yang ada, dalam konsep kausalitas serta faktor-faktor kondisional yang cenderung memaparkan peristiwa sejarah secara naratif dengan memaparkan secara kronologis dalam hubungan tempat dan waktu.

Pengumpulan sumber dalam penelitian ini menggunakanberbagai sumber. Wawancara terhadap pelaku atau saksi, karena pelaku sejarah masih hidup. Kemudian Arsip Daerah Jawa Timur, Arsip Departemen Sosial Politik Jawa Timur, Arsip Kabupaten Sampang, Arsip Nasional Republik Indonesia, laporan Komisi Pemilihan Umum (KPU) 1971-1997 Daerah Jawa Timur dan KPU Sampang, agar mendapat sumber atau informasi yang benarbenar valid, kredibel, dan konprehensif. Sumber sebagai bahan penunjang seperti buku, Karya Tulis seperti artikel meskipun terbatas penting juga untuk dijadikan perbandingan untuk melengkapi informasi, dan yang tidak kalah pentingnya adalah surat kabar dan majalah hampir semua surat kabar tingkat nasional dan lokal.

Kemudian melakukan kritik terhadap semua sumber yang didapat, yaitu seperti yang lazim dalam sejarah kritik ekstern dan kritik intern. Dalam pelaksanaanya kritik ekstern lebih menitik berartkan terhadap originalitas yang dipakai membuat dokumen, sedangkan kritik intern lebih memertimbangkan kebenaran isi sumber atau dokumen. ${ }^{18}$ Kritik ekstern bertujuan menjawab tiga pertanyaan pokok yang dikaitkan bahan dari sumber sejarah atau dokumen yang telah berhasil dikumpulkan.Kritik intern juga berkaitan dengan faktor-faktor kemampuan, penguasaan ilmu bantu, keyakinan, atau kepercayaan, status atau prasangka si pengarang. ${ }^{19}$ Setelah kritik tahap yang terakhir adalah historiografi dengan

\footnotetext{
17 Louis Gotschalk, Mengerti Sejarah, Jakarta: Universitas Indonesia Press, 1982, hlm. 34.

18 Aminuddin Kasdi, Memahami Sejarah, Surabaya: Unesa University Press, 2005, hlm. 27-28.

${ }^{19}$ Louis Gotschalk, op. cit., hlm. 81-83.
}

menggunakan metode historical explanation seperti yang dikatakan oleh Kuntowijoyo.

\section{HASIL DAN PEMBAHASAN \\ a. Persaingan Para Kiai}

Lahirnya PKB sebagai partai politik yang dikampanyekan sebagai partai NU terbukti sangat efektif. Menurut Kiai Muhammad Ishak $^{20}$ adanya PPP sebagai partai fusi dari berbagai partai Islam tidak menguntungkan bagi NU PPP lebih didominasi oleh golongan non NU. Menurutnya secara nasional tokohtokoh NU terpinggirkan tidak menduduki jabatan yang strategis meskipun sebenarnya massa terbesar PPP adalah warga NU sendiri, dengan lahirnya PKB maka warga NU memunyai rumah sendiri untuk mengaspirasikan kepentingannya. Komaruddin Hidayat juga mengatakan meskipun NU memunyai massa yang terbesar, tapi hanya memeroleh jatah sedikit. $^{21}$

Lahirnya PKB menjadi petanda penting dalam sejarah politik Masyarakat Sampang.Terjadi imigrasi politik massa di Sampang secara besar-besaran diawali oleh para kiaiyang hampir seluruhnya berpindah kePKB. Fenomena ini sangat menarik karena sebelumnya hampir seluruh kiai di Sampang menjadi pendukung setia PPP dengan berbagai simbol perjuangan keislaman. Tercatat dari Sembilan puluh delapan pondok pesantren yang ada di Sampang hanya limakiai yang masih setia di PPP. KH Zainal Abidin Pengasuh Pondok Pesantren Aeng Cellep, Kiai Fannan Pengasuh Pondok Pesantren Kajuk, Kiai Yahya dari Pondok Pesantren Prajjan, dan Kiai Ali Karrar Pengasuh Pondok Pesantren Lenteng Proppo, $^{22}$ dan tentunya Kiai Alawy

${ }^{20}$ Kiai Muhammad Ishak Ketua Partai Anak Cabang PKB Sampang, sebelum PKB lahir sejak 1983 sudah aktif di Partai Politik PPP di Sampang, kemudian saat PKB dideklarasikan ia termasuk salah satu tokoh Sampang yang berpindah hlmuan politik ke PKB.

${ }^{21}$ Bola Politik Sekarang Ada di Kaki NU, Jawa Pos, 1Juli-1998, hlm., 3.

${ }^{22}$ Sebenarnya Lenteng Proppo secara adimistrasi masuk dalam Kabupaten Pamekasan namun secara geografis berbatasan dengan Sampang. banyak santri yang berasal dari Sampang, Kiai Karrar juga dikenal di 
Muhammad Pengasuh Pondok Pesantren AtTaroqqi Karongan sebagai pemuka PPP yang sebelumnya sangat disegani. ${ }^{23}$

Ada beberapa alasan yang membuat limakiai ini masih bertahan di PPP. Kiai Alawy Muhammad masih bertahan di PPP karena bukan berasal dari kalangan NU ia adalah Kader Persatuan Islam (Persis). Alasan yang sangat mendasar karena namanya dibesarkan oleh PPP, dan menjadi orang yang sangat penting, meskipun jabatannya sekadar Ketua Dewan Syuro (MPP). Sangat wajar ia tetap memerjuangkan PPP hingga akhir hayatnya. Bisa dikatakan tidak mungkin baginya untuk berpindah partai. Kiai zainal Abidin dan Kiai Ali Karrar memunyai kedekatan dengan Kiai Alawy Muhammad bahkan Kiai Ali Karrar dan Kiai Alawy Muhammad ada hubungan keluarga. Selain itu sikap Gusdur yang terkenal liberal dengan predikat pluralisme tidak bisa diterima oleh beberapa kiai yang salaf seperti Kiai Ali Karrar.

Kiai Zainal Abidin dan Kiai Ali Karrar terkenal sangat keras dan lantang dalam menyuarakan Agama Islam, bahkan Pondok Pesantren Lenteng Proppo dikenal dengan aturan yang sangat ketat. Kerasnya pemikiran Kiai Ali Karrar ditunjukkan dengan penolakan terhadap musik dan pertunjukan pengantin yang disanding di panggung dekorasi. Ia menghindari hal-hal yang syubhat dan khilafiah maka tidak mengherankan apabila pemikirannya bersebrangan dengan Gusdur yang dikenal memunyai pemikiran yang liberal. Sedangkan Kiai Fannan tetap bertahan di PPP karena pengurus PPP yang masih aktif, dengan kata lain ia memertahankan jabatannya. Kiai Yahya Prajjan juga masih aktif sebagai anggota dewan DPRD Sampang yang berasal dari Fraksi PPP. ${ }^{24}$

Sampang dan sering berceramah dan Jurkam di wilayah Sampang, maka ia memunyai pengaruh di Sampang dalam menentukan pilihan partai politik para ustadznya juga banyak yang ditugaskan di madrasah Sampang.

${ }^{23}$ Wawancara dengan Kiai Muhammad Ishak, 4Maret-2015, di Komis Kedungdung.

${ }^{24}$ Wawancara dengan Kiai Muhammad Ishak.
Wacana ke NU-an yang digelontorkan di Sampang berjalan sangat massif dan efektif. Kebesaran namaGusdur yang menjabat sebagai Ketua Umum PBNU juga sangat memengaruhinya, kepiawaian Gusdur dalam percaturan high politics tidak ada yang meragukan. Bahkan pengamat politik Herbert Feith menyebut Gusdur sebagai politikus kelas satu. ${ }^{25}$ Menurut Kiai Muhammad Ishak Gusdur adalah keturunan langsung dari pendiri NU KH Hasyim Asyari wajar apabila mendapat tempat yang istimewa dalam masyarakat Sampang. Dengan mereproduksi heroisisme perjuangan $\mathrm{KH}$ Hasyim Asyari melawan Belanda (orang kafir) secara langsung membentuk romantisme masa lalu seorang ulama berjuang melawan orang kafir. $^{26}$ Fanatisme ke NU-an bagi orang Madura bukan sesuatu yang asing didengar, bahkan ada anekdot bahwa "Agama orang Madura adalah NU". Ormas ini memiliki tempat istimewa dalam masyarakat Madura karena tidak terelepas dari simbol ulama yang menjadi aktor-aktor pentingnya.

Banyak alasan kiai di Sampang hijrah ke PKB. Popularitas dan pengaruh Kiai Alawy Muhammad sebelum tragedi 1997 dianggap mensubordinasi kiai-kiai yang lain karenanya para kiai hanya menjadi ekor dan menyetujui semua garis politik kiai Alawy Muhammad. Hegemoni Kiai Alawy Muhmmad tidak dapat direduksi sehingga apabila ada kebijakan dan keputusan musyawarah yang sebenarnya tidak disetujui oleh parakiai yang lain kebijakan tersebut tidak bisa dirubah. ${ }^{27}$

Untuk kepentingannya seringkali Kiai Alawy Muhammad memainkan politik ala Machiavelli. Hal itu pernah disampaikan oleh Marzuki Nahrawi yang menjadi korban politiknya. Marzuki Nahrawi sekitar tahun

\footnotetext{
${ }^{25}$ Gusdur Pun Siap Turun Gunung, Jawa Pos $27-$ Juli-1998, hlm., 3.

${ }^{26}$ Kiai Muhammad Ishak mengatakan bahwa Gusdur sebagai keturunan KH Hasyim Asyari sangat memengaruhi oreng kenek. KH. Hasyim Asyari dikenal sebagai pendiri NU dan pejuang kemerdekaan melawan Penjajah Kolonial Belanda (kafir), bahkan ada masyarakat yang menaruh poto atau gambar $\mathrm{KH}$. Hasyim Asyari di tembok-tembok rumhanya.

27 Wawancara dengan Marzuki Nahrawi, 18 September 2014.
} 
1993 sebenarnya secara otomatis menjadi anggota DPRD mengantikan Saleh Hadi dari NU yang meninggal dunia, karena pemilu 1992 Marzuki Nahrawi tidak terpilih lagi menjadi DPRD. Dalam AD/ART partai ketika ada anggota DPRD meninggal atau mengundurkan diri yang berasal dari NU maka secara otomatis digantikan urutan suara terbanyak selanjutnya. Tetapi Marzuki Nahrawi gagal menjadi anggota DPRD karena permainan Kiai Alawy Muhammad menolak pergantian otomatis. Menurutnya harus dipilih lagi dalam musyawarah partai, padahal aturan partai sudah jelas digantikan secara otomatis. Tidak ada satupun yang berani melawan hanya Marzuki Nahrawi yang tetap memerjuangkan haknya meskipun pada akhirnya harus tersingkir.

Perjuangan para kiai di PPP mengalami kejenuhan karena seringkali dikecewakan hasil yang diperoleh tidak sesuai ekspektasi. Perjuangan hingga meletusnya tragedi 1997 yang menelan banyak korban tetap saja tidak membuahkan hasil yang diharapakan meskipun pemilu diulang di 67 TPS. Misi yang tidak tersampaikan dengan baik selama di PPP menjadi alasan yang juga penting dalam memengaruhi hijrahnya para Ulama. Lahirnya PKB menjadi alternatif baru untuk memerjuangkan Islam dalam pentas politik di Indonesia.

Pada Pemilu 1999 tebukti adanya imigrasi politik besar-besaran ke partai baru, ke Partai Amanat Nasuional (PAN) dan PKB. Partai baru berhasil berselancar di atas gelombang kekecewaan kiai dan oreng kenek sekaligus menawarkan harapan baru. Arus kekecewaan selalu mengalir ke tempat atraktif yang dinilai menjanjikan ada harapan. Masyarakat Sampang yang dikenal dengan oreng kenektermasuk dalam kategori pemilih tradisional yang berpatron dalam menentukan politiknya, berbeda dengan pemilih rasional yang relatif mandiri dan mampu mengekspresikan dukungan dan penolakannnya secara mandiri. Satu-satunya figur yang dijadikan patron adalah kiai maka bukan hal yang mengherankan jika imigrasi Ulama Sampang secara otomatis diikuti oleh massa (oreng kenek).
PKB tampil sebagai alternatif dengan diferensiasi yang nyata dari partai politik lainnya. Diferensiasi politik diperkuat oleh perangkat-perangkat kepimimpinan dan ketokohan yang menjanjikan, popularitas yang massif seperti seorang Gusdur, serta platform yang jelas dan kuat, jaringan yang luas dan mampu menembus akar rumput. PKB yang memainkan wacana ke NU-an dengan berpegang teguh pada doktrin Ahlusunnah Waljamaah dengan misi Agama, tapi tetap menjungjung tinggi wawasan kebangsaan mampu menembus akar rumput yang mayoritas warga NU. Wacana, kampanye bahwa PKB adalah partai-nya orang NU menjadi alasan yang sangat mendasar bagi Ulama berpindah haluan ke $\mathrm{PKB}^{28}$ Gusdur dalam sambutannya disaat deklarasi PKB mengatakan "Diharapakan warga NU yang ikut dalam pemilu nanti mencoblos $\mathrm{PKB}$, dengan berdirinya PKB sempurnalah perangkat PBNU untuk mendirikan partai semua kiai telah memberikan restu untuk berdirinya partai ini". 29

Imigrasi politik besar-besaran para Kiai Sampang ke PKB dianggap mengancam kedudukan Kiai Alawy Muhammad massa PPP dikuatirkan akan ikut berpindah haluan. Dalam kondisi seperti itu ada persaingan sangat intensif diinternal para kiai. Golongan kiai yang masih konsisten mendukung PPP yang digawangi oleh Kiai Alawy Muhammad yang popularitasnya mulai meredup dan kiai yang memunyai ijtihad politik yang berbeda untuk hijrah ke PKB. Namun persaingan tersebut bisa dikatakan tidak seimbang, kelompok kiai PPP jumlahnya jauh dibawah para kiai yang telah hijrah ke PKB.

Kelompok kiai PPP bukan hanya tidak diuntungkan dengan jumlahnya yang sedikit, tetapi serangan yang paling efektif

28 Wawancara dengan $\mathrm{KH}$ Muqowwim Padmo mantan anggota DPRD Sampang fraksi PKB, pada 20-Januari-2015 di Banmote Sampang, dan wawancara dengan Kiai Muhammad Ishak, pada 4Maret-2015, di Komis Sampang.

${ }^{29}$ Bersmisi Agama, menjunjung Kebangsaan, Jawa Pos, 24 Juli 1998, hlm. 2. 
dilancarkan oleh kelompok PKB adalah propaganda bahwa PPP bukanlah partai NU. Selain itu PPP dikerdilkan dengan sebutan kelompok pro status quo. Reformasi dan reformis menjadi komoditas politik, untuk menarik perhatian dan simpati, demikian juga reformasi dan status quo menjadi senjata untuk mengangkat $\mathrm{PKB}$ dan menyudutkan PPP. Berbeda dengan kelompok kiai PKB mereka bukan hanya diuntungkan dengan wacana ke NU-an dan pro reformasi tetapi rekam jejak PPP dalam pemilu selama pemerintahan Orde Baru relatif kurang baik karena dua kali pemilu terakhir dikalahkan Golkar hingga menuai perlawanan yang menewaskan banyak korban dan tidak mampu dituntaskan oleh Kiai Alawy Muhammad.

Kuatnya penggiringan opini publik yang sedang ramai diperbincangkan bahwa PKB adalah partai yang pro reformasi dan rumah bagi warga NU, sedangkan PPP diposisikan sebagai partai pro status quo. Dalam kondisi seperti itu, partai-partai yang dikategorikan pro reformasi jelas sangat diuntungkan. Sebaliknya partai-partai yang terkategori pro status quo terugikan. ${ }^{30}$ Reformasi adalah semangat demokratisasi sebagai inti yang kemudian dijabarkan dalam isu populer dan serius seperti pemberantasan KKN (krupsi, kolusi, dan nepotisme), penegakan hukum, keadilan, dan perwujudan hak-hak asasi manusia. ${ }^{31}$ Tentu saja dalam konteks pemilih Sampang hanya PKB satu-satunya partai pro reformasi yang menjadi alternatif.

Para kiai PKB juga mulai memerbincangkan latar belakang Kiai Alawy Muhammad yang berasal dari Persis dan mulai menkontradiksikan dengan NU (Kiai Alawy Muhammad bukan orang NU), padahal sebelum PKB didirikan tidak pernah ada sedikitpun yang memermasalahkan latar

30 Kacung Marijan, Ketika Makna Reformasi Dipahami Secara Berbeda, dalam (Dari Bilik Suara Ke Masa Depan Indonesia; Potret Konflik Politik Pasca Pemilu dan Nasib Reformasi), Jakarta: RajaGrafindo Persada, 1999,hlm., 49.

31 Manuel Kaisiepo, Fenomena Parta-Partai Politik Baru, dalam (Memilih Partai Mendambakan Presiden; Belajar Berdemokrasi di Ufuk Milenium), Bandung: Rosdakarya, 1999, hlm 93. belakang organisasinya. Kondisi yang tidak menguntungkan tersebut dirasakan oleh Kiai Alawy Muhammad sangat mengancam akseptabilitas dan popularitasnya.

Opini yang terus memojokkan PPP dan Kiai Alawy Muhammad kemudian mendapat perlawanan dari pihak PPP yaitu Kiai Alawy Muhammad dan Kiai Zainal Abidin. Tetapi perlawanan yang dialakukan oleh kedua kiai tersebut cenderung menggunakan cara-cara klasik dan tidak kreatif. Masyarakat Sampang masih diselimuti kekecewaan dan duka pasca-tragedi 1997, tapi KiaiAlawy Muhammad menggunakan carayang sama seperti sebelumnya. Jika sebelumnya Golkar yang diserang dengan berbagai hujatan dan kecaman, saat itu PKB yang menjadi serangan dalam setiap kesempatan. Kiai Alawy Muhammad tidak segan-segan mengafirkan semua kiai PKB tidak hanya kiai PKB Sampang yang mendapat serangan namun Kiai Sidogiri juga dihujat oleh Kiai Alawy Muhammad hingga mendapat kecaman yang keras dari santri-santri Sidogiri. ${ }^{32}$

Kejadian itu membuat santri-santri Sidogiri marah besar melaporkan ke Polisi atas pencemaran namabaik hingga mereka berdamai. ${ }^{33}$ Serangan Kiai Alawy Muhammad dalam pembunuhan karakter juga ditujukan kepada Gusdur dalam setiap kesempatan berceramah ketika masih diundang sebagai penceramah dalam pengajian yang diadakan oleh masyarakat. Ia tidak segan-segan mengatakan bahwa Gusdur seorang $\mathrm{PKI},{ }^{34}$ harus dijauhi karena sangat berbahaya.

32 Wawancara dengan Kiai Muqowim Padmo yang juga Alumni Sidogiri, 20-Januari-2015, di Banmote Sampang.

${ }^{33}$ Ibid.

${ }^{34}$ Statmen-statmen ini masih bisa di putar di Youtube dengan memasukkan kalimat "Ceramah Kiai Alawy Muhammad", sekitar ada dua postingan, ada judul "KH Alawy Muhammad" dan satunya "PKB Kafir... Versi KH. Alawy Muhammad". Gusdur tidak hanya dikatakan PKI tetapi juga dikatakan orang yang benci terhadap Islam. Kemudian di postingan yang berjudul "PKB Kafir... Versi KH Alawy Muhammad", PKB dikatakan Kafir Harbi dan Salatnya tidak diterima. 
Cara Kiai Alawy Muhammad untuk memertahankan basis massa PPP tidak berbeda dengan sebelumnya disaat PPP dibenturkan dengan Golkar. Tetapi ia tidak sadar bahwa saat itu kondisinya berbeda jauh dengan sebelumnya, PKB bukanlah partai pemerintah seperti Golkar bahkan PKB adalah partai yang telah didukung oleh para kiai di Sampang. Ia juga tidak menyadari bahwa Rezim Orde Baru teh tumbang media massa benar-benar sedang menikmati kebebasan dan tentunya sangat berperan dalam menciptakan kondisi yang menguntungkan PKB. Perlawanan Kiai Alawy Muhammad menjadi boomerang baginya lambat laun hujatan-hujatannya menciptakan kuburannya sendiri.

Beberapa narasumber yang penulis wawancarai seperti Muyassir Abdullah, dan ustadz Muhksin mengatakan bahwa keyakinannya semakin mantab ketika mereka sering mendengar Kiai Alawy Muhammad mengafirkan kiai PKB dan orang-orang yang hijrah ke PKB. Mereka mampu berpikir rasional setelah sekian lama didoktrin hitam putih tentang politik, apalagi keduanya adalah Alumni Pondok Pesantren Al-Ihsan Jerengoan yang diasuh oleh Kiai Mahrus Maliki, seorang kiai yang cukup berpengaruh dan telah hijrah ke PKB.

Pada dasarnya masyarakat Sampang menghormati semua kiai di Sampang, tetapi penghormatan dan kepatuhan tehadap kiai tidak melebihi "kiainya sendiri" atau gurunya sendiri. Artinya setiap masyarakat memiliki kiai atau guru sendiri yang didasarkan pada tempat mereka menuntut ilmu (mondok) yang secara berkelanjutan diteruskan oleh anakanakya kelak. Di tiap-tiap daerah berbeda, ada penyebaran karena jumlah pondok pesantren di Sampang sangat banyak. Tetapi hanya Kiai Alawy Muhammad saat itu (sebelum tragedi 1997) yang menjadi satusatunya kiai paling dihormati oleh seluruh masyarakat.

Adanya beberapa kiai yang masih bertahan di PPP masing-masing juga memunyai pondok pesantren cukup besar maka basis massa PPP tidak hijrah ke PKB secara keseluruhan. Santri-santri dari keempat kiai PPP masih setia pada kiai mereka, karena membela guru (kiai) ${ }^{35}$ adalah kebanggaan. Bagi massa yang tidak dipengaruhi oleh faktor dan latar belakang tersebut mereka memilih hijrah ke PKB sebagai partai warga NU dan harapan baru. Posisi Kiai Alawy Muhammad semakin hari semakin terjepit dan popularitasnya semakin menurun, namun dalam kondisi seperti itu ia terus melanjutkan serangan-serangannya terhadap kiai-kiai PKB sehingga pada akhirnya pengaruhnya memudar sama sekali.

\section{b. Aktor-Aktor Penting}

Secara umum PKB merekrut anak-anak muda untuk posisi-posisi penting ${ }^{36}$ tampilnya tokoh-tokoh muda dalam kepengurusan PKB menjadi keistimewaan tersendiri bagi partai tersebut. Muhaimin Iskandar yang menjabat sebagai Sekjen DPP dan Yahya Cholil Staquf sebagai Wakil sekjen adalah bukti bahwa anak-anak muda NU memunyai peran penting dalam PKB. Muhaimin dan Yahya adalah pengurus Angkatan Muda NU (AMNU). ${ }^{37}$ Organisasi AMNU didirikan sebagai organisasi kader, baik untuk NU maupun untuk PKB, AMNU menjadi wadah bagi anak-anak muda NU.

Dalam rentang waktu yang relatif singkat 1998 hingga pemilu 1999 PKB suskes mengonsolidasikan kepentingan partai. Dalam studinya, Afan Gaffar menyimpulkan faktor sosio-religius-kultural menjadi determinan utama dalam pemilu di desa di Jawa. ${ }^{38}$ Maka tidak mengherankan apabila PKB sebagai partai yang baru didirikan mendapat dukungan yang besar dari masyarakat khususnya Jawa yang memiliki penduduk terbesar di Indonesia. Berdasarkan statistik dapat disimpulkan pendukung partai

\footnotetext{
${ }^{35}$ Guru disini tidak berarti umum, karena hanya guru kiai yang mendapat penghormatan dan kepatuhan yang istimewa, tidak untuk guru yang lain, misalkan guru sekolah umum SD atau SMP dan seterusnya. Karena bagi mereka kiai telah mengajarkan pengetahuan Agama yang akan membawa mereka masuk surga.

${ }^{36}$ Gusdur Pun Siap Turun Tangan, ibid.,

${ }^{37}$ Ibid.

${ }^{38}$ Asvi Warman Adam, Perilaku Pemilih, dalam "Dari Bilik Suara Ke Masa Depan Indonesia; Potret Konflik Politik Pasca Pemilu dan Nasib Reformasi", Jakarta: RajaGrafindo Persada, 1999,hlm., 34.
} 
berbasis Islam, baik saat pemilu 1955 maupun pemilu 1999, sebenarnya berada di atas angka statistik pemeluk Islam yang taat syariah. $^{39}$

Secara sosio-kultural, massa umat yang cenderung tidak taat syariah bukan karena rendahnya komitmen keagamaan mereka, tapi karena kecenderungan elitis dari hukum formal syariah. Hal ini tidak hanya dialami oleh gerakan Islam tetapi berbagai gerakan keagamaan seperti Kristen dengan lembaga gerejanya. Bagi mayoritas umat lapis bawah, buruh atau petani miskin, pusat kehidupan mereka bukanlah keagamaan formal melainkan dunia spiritual sebagai akibat belitan kemiskinan yang membuat mereka tidak jelas. Oleh karenanya tradisi slametan, kenduri, tahlilan dan berbagai kegiatan budaya berbau Islam lainnya jauh lebih penting daripada ibadah formal. ${ }^{40}$

Dalam hubungan inilah gerakan PKB sebagai partai NU memiliki basis kultural yang membuat gerakan ini lebih dekat pada kehidupan lapis bawah yaitu oreng kenek. Menurut Kuntowijoyo (2002: 2) secara geografis, historis dan kultural Madura merupakan bagian dari Jawa. Tradisi slametan, kenduri, tahlilan juga dilakukan oleh orang Madura karena pada dasarnya kedua suku ini dibentuk dengan sejarah yang sama yaitu Kerajaan Majapahit. Namun orang Madura selain menjalankan ritual-ritual non keagamaan mereka juga digolongkan orang yang taat beribadah secara formal. Bahkan sebagai masyarakat dengan tingkat pendidikan yang rendah, simbol, slogan, dan jargon menjadi komunikasi yang lebih efektif.

Fakta sosio-religius-kultural disadari betul oleh para elit PKB apalagi hal tersebut menjadi taken for granted bagi PKB yang merupakan partai produk NU Ormas Islam tradisional. Berbeda misalnya dengan Partai Amanat Nasional (PAN) meskipun merupakan Partai reformasi yang digawangi tokoh besarnya Amin Rais, PAN tidak memeroleh suara yang signifikan.

\footnotetext{
39 Abdul Munir Mulkan, 1999, Memahami Perilaku Pemilih,Ibid.hlm., 36.

${ }^{40}$ Ibid.,
}

Penyebabnya PAN dikesankansebagai partainya Muhammadiah, identitas kelas elit kaum terpelajar dan kurang mengembangkan pendekatan kultural mayoritas pemilih buruh dan petani. ${ }^{41}$ Bahkan di Sampang Muhammadiah sama sekali tidak diterima oleh masyarakat Sampang. Partai ini cenderung berjaya di kota-kota besar di mana terdapat perguruan tinggi yang komunitasnya cenderung kritis seperti Yogyakarta atau yang dikenal partai berbasis Islam modernis seperti Sumatera Barat. ${ }^{42}$

Kesuksesan PKB di Sampang juga tidak terlepas dari kaum muda yang bergerak secara serentak dan sistematis. Pengurus PKB di Sampang diambil dari Pengurus Cabang Nahdlatul Ulama (PCNU) dengan ketuanya $\mathrm{KH}$ Masykur Rozak, dan Majelis Wakil Cabang Nahdlatul Ulama (MWCNU) ketuanya dijabat Kiai Muhammad. ${ }^{43}$ Mayoritas pengurus PKB dijabat oleh para kiai muda, seperti KH Masykur Rozak, Kiai Muhmmad, Kiai Zainol, Kiai Mahsyar, Kiai Muhammad Ishak, dan kiai-kiai lainnya. ${ }^{44}$ Penunjukan kiai sebagai pengurus PKB bertujuan untuk memudahkan komunikasi dan transformasi ideologi PKB terhadap massa, karena kiai lah yang mampu diterima dengan baik oleh masyarakat.

Ketika PKB telah selesai dibentuk semua Ulama di Sampang bergerak secara serentak ${ }^{45}$ dengan berbagai strategi. Memisahkan secara ketat antara PPP dan PKB bahwa PPP bukan partai warga NU sedangkan PKB partai warga NU menjadi wacana yang sangat dominan. Menyadari bahwa masyarakat Sampang hampir seluruhnya NU maka wacana pemisahan dikembangkan lagi lebih spesifik yaitu pemisahan antara warga NU dan warga non $\mathrm{NU}^{46}$ artinya strategi tersebut dilakukan untuk menarik massa yang masih mengambang karena dilematis menentukan pilihan PPP atau PKB. Pemisahan secara

\footnotetext{
${ }^{41}$ Abdul Munir Mulkan, Ibid., hlm. 38.

${ }^{42}$ Ibid.,

${ }^{43}$ Wawancara dengan Kiai Muhmaad Ishak 4-Maret2015

${ }^{44}$ Ibid.,

${ }^{45}$ Ibid.,

${ }^{46}$ Ibid.,
} 
ketat untuk menegaskan kembali bahwa kalau warga NU silahkan bergabung dengan PKB agar tidak terkucilkan oleh warga yang lain.

Ada aktor-aktor muda atau kelompok yang juga penting dan berperan besar untuk menyosialisasikan PKB dan meyakinkan masyarakat untuk memilih PKB. Setiap kampung atau dusun ada madrasah dan masjid yang diasuh oleh Kyaeh Kenek (kiai kampung) tenaga pendidiknya adalah seorang ustadz lulusan pondok pesantren yang sengaja dikirim oleh Ponpes tersebut sebagai tugas pengabdian. Biasanya pondok pesantren yang banyak mengirim ustadznya adalah pondok pesantren besar seperti Ponpes Al-Ihsan Jerengoan, Ponpes Nangger Sempal, Ponpes Enjelen, Ponpes di Tambelangan, yang semua pengasuhnya (kiainya) telah hijrah ke PKB. Kemudian diikuti oleh Ponpes Lenteng Proppo dan Ponpes At-Taroqqi Karongan yang masih bertahan di PPP.

Interaksi ustadz dengan masyarakat setempat secara langsung maupun tidak langsung mentransformasikan keberpihakan kiai mereka terhadap PKB. Ustadz dihormati dan juga cukup memiliki nilai prestis dalam masyarakat karena indikator pengetahuan Agamanya dan juga dianggap orang yang telah sukses menuntut ilmu Agama di Ponpes dan dipercaya oleh Ponpes (kiai). Ustadz ini lazim disebut dengan "ustadz tugas", karena mereka mengemban amanah Ponpes atau kiai untuk mengabdikan dirinya di madrasahmadrasah yang kelak biasanya para peserta didiknya akan menjadi calon santri pondok yang bersangkutan.

Ustadz biasanya bertugas mengajar selama setahun atau bisa tiga tahun setelah itu diganti lagi dengan ustadz yang baru yang berasal dari satu ponpes dan itu terjadi secara terus menerus. Tidak jarang ada ustadz pada akhirnya menikahi santrinya sendiri, tanpa melewati proses yang sulit ustadz diterima dengan baik oleh orang tua yang bersangkutan bahkan merupakan kebanggaan anaknya dinikahi seorang ustadz. Hubungan yang baik antara ustadz dengan masyarakat setempat memengaruhi dukungan masyarakat terhadap PKB. Ustadz tidak hanya menyebarkan pengaruh dalam masyarakat untuk hijrah ke PKB mereka juga tidak jarang mendoktrin santri-santrinya untuk berpihak dan simpati terhadap PKB dan meninggalkan PPP. ${ }^{47}$

Jumlah ustadz yang berasal dari Ponpes kiai PKB jauh lebih banyak daripada ustadz yang berasal dari Ponpes kiai PPP meskipun bisa saja ustadz-ustadz yang berasal dari Ponpes kiai PPP juga melakukan hal serupa. ${ }^{48}$ Gerakan yang dilakukan oleh PKB kemudian membuahkan hasil yang maksimal PKB menang mutlak di Sampang, ${ }^{49}$ berbanding terbalik dengan perolehan suara PPP yang menurun drastis apalagi Golkar.

PKB yang baru kali pertama mengikuti pemilu 1999 mendulang suara hingga mendapatkan 18 kursi di DPRD Sampang, sedangkan PPP hanya memeroleh 12 kursi, bahkan Golkar hanya 2 kursi kalah dari PDIP yang memeroleh 5 kursi. $^{50}$ Perolehan suara Gokar yang sangtat rendah (hanya dua kursi) sekali lagi mengafirmasi bahwa pemilu 1992 dan 1997 yang memenangkan Golkar mutlak dilakukan dengan kecurangan dan intimidasi, di sisi lain, perolehan suara PPP yang menurun drastis namun masih berada di urutan kedua karena masih ada beberapa kiai yang bertahan di PPP juga mengonfirmasi bahwa kultur paternalistik (ketokohan kiai) sangat berpengaruh di Sampang.

\section{SIMPULAN}

Kultur politik Masyarakat Sampang bersifat paternalistik, termasuk dalam kategori pemilih tradisional yang berpatron dalam menentukan politiknya. Berbeda dengan pemilih rasional yang relatif mandiri

47 Diskusi dengan Kuseiri alumni Madrasah Nurul Huda Pelanggaran Kedungdung Sampang.

48 Penulis belum bisa memastikan apakah ustadz yang berasal dari Ponpes kiai PPP juga melakukan hal serupa, karena penulis belum mewawancarainya. Tetapi stigma buruk terhadap Kiai Alawy Muhmmad cukup membuat ustadz ini tidak percaya diri.

${ }^{49}$ Pernyataan Ketua DPW PKB Khoirul Anam dalam salah satu media pada 2-april-2004.

50 Moch. Nurhasim, Pengaruh dan Kekuatan Kiai Dalam Rekruitmen Politik: Kasus Kabupaten Sampang dan Pasuruan, dalam (Pemilu Langsung di Tengah Oligarki Partai: Proses Nominasi dan Seleksi Calon Legislatif Pemilu 2004), Jakarta: Gramedia, 2005, hlm., 29. 
dan mampu mengekspresikan dukungan dan penolakanya secara mandiri. Satu-satunya figur yang dijadikan patron adalah kiai. Kemenagan PKB adalah fakta bahwa Islam dan kiai menjadi entitas penting dan sakral bagi Masyarakat Sampang. Bahkan PPP masih menempati urutan kedua meskipun secara politik kedua partai ini bersaing.

Imigrasi para kiai dan masa ke PKB tidak secara otomatis menenggelamkan PPP. PPP masih menempati urutan kedua karena masih ada beberapa kiai yang mendukungnya. Tetapi membenamkan Golkar yang sebelumnya selalu mendapat suara massif, dan dua pemilu terakhir sebelum reformasi (1992 dan 1997) keluar menjadi pemenang. Kemenagan Golkar di Sampang pada zaman Orde Baru adalah kemenangan formal bukan representasi dari keinginan Masyarakat Sampang. Golkar melakukan operasi birokrasi, kecurangan, dan bahkan intimidasi untuk memenangkannya. Kenyataan tersebut semakin terungkap pasca-reformasi, Golkar hanya memeroleh dua kursi di DPRD dengan urutan suara paling buncit di bawah Partai Demokrasi Indonesia.

Sosok kiai menjadi figur sentral sebagai tokoh karismatis yang memiliki kekuatan adiduniawi. Masyarakat Sampang adalah sebuah komunitas yang memiliki tradisi kepatuhan yang tinggi terhadap kiai. Segala persoalan kehidupan sering kali jika tidak dikatakan selalu dikonsultasikan kepada kiai. Realitas sosial, politik, dan keagamaan tersebut juga didasari oleh beberapa sebab yaiturendahnya tingkat pendidikan, bahkan banyak yang buta huruf,kemiskin, religius, mereka hidup secara homogen. Sehingga rumor, slogan, simbol lebih berpengaruh daripada komunikasi massayang efektif, melalui slogan surga-neraka, jihad membela agama, hegemoni kiai bersemai.

\section{DAFTAR PUSTAKA}

Adam, Asvi Warman. 1999. Perilaku Pemilih, dalam "Dari Bilik Suara Ke Masa Depan Indonesia; Potret Konflik Politik Pasca Pemilu dan
Nasib Reformasi". Jakarta: RajaGrafindo Persada.

Aminuddin Kasdi. 2005.Memahami Sejarah. Surabaya: Unesa University Press.

Burke, Peter. 2011. Sejarah dan Teori Sosial. Jakarta: Pustaka Obor.

Gostcalk, Louis. 1982. Mengerti Sejarah, Jakarta: Universitas Indonesia Press.

Jones, Pip. 2010. Pengantar Teori-Teori Sosial; Dari Teori Fungsionalisme Hingga Post-modernisme. Jakarta: Yayasan Obor.

Johnson, Doyle Paul. 1988. Teori Sosiologi Klasik dan Modern. Jakarta: Gramedia.

Kaisiepo, Manuel. 1999. Memilih Partai Mendambakan Presiden; Belajar Berdemokrasi di Ufuk Milenium. Bandung: Rosdakarya.

Kumpulan Dokumen KPU 1971-1999. No 711. ANRI.

Kumpulan Dokumen KPU 1971-1999. No 712. 2. ANRI

Kuntowijoyo. 1997. Identitas Politik Umat Islam. Bandung: Mizan.

Marijan, Kacung. 1999. Dari Bilik Suara Ke Masa Depan Indonesia; Potret

Konflik Politik Pasca Pemilu dan Nasib Reformasi. Jakarta: RajaGrafindo Persada.

Mulkan, Abdul Munir. 1999. Memahami Perilaku Pemilih. Jakarta: RajaGrafindo Persada.

Nurhasim, Moch. 2005. Pemilu Langsung di Tengah Oligarki Partai: Proses Nominasi dan Seleksi Calon Legislatif Pemilu 2004. Jakarta: Gramedia.

Jawa Pos. 31-Juni-1998. Halaman 4.

Jawa Pos. 1-Juli-1998. Halaman 3.

Jawa Pos. 24-Juli-1998. Halaman 1.

Jawa Pos. 27-Juli-1998. Halaman 3.

Kompas Amanat Hati Nurani Rakyat. Peran

Politik Ormas Islam. 20 Juni 2015. 